\title{
The Effect of External Debt in the Economic Growth of Pakistan
}

\author{
Sadaf Mustafa \\ Assistant Professor, Department of Commerce, University of Karachi \\ Muhammad Mashhood Ahmed \\ Phd Scholar, Department of Commerce, University of Karachi \\ Syed Shoeb Ahmed \\ Department of Public Administration, University of Karachi
}

\begin{abstract}
This study evaluates the impact of external (or foreign) debt on the economy of Pakistan. For the purpose of this research, 12-years macroeconomic data was obtained from credible publications of State Bank of Pakistan and statistics reported in World Bank database. In order precisely and accurately measure the impact for the given period, this research first presented an extensive review of historic trend of Pakistan's GDP and external debt relation over the vast period between 1950s to 2005.Time series data is collected from the World Bank site for the last thirty years ranges from 1986-2015. Statistics analysis and ordinary least square regression is performed through a descriptive statistical table. To check the relationship between economic growth and external debt OLS model is used. GDP is our dependent variable. Gross domestic saving, gross capital formation and external Debt stock is our independent variable. The results show that the huge amount of number of GDP of country is backed by external debt.
\end{abstract}

Keywords: External Debt, Economic Growth, Trend of Pakistan's GDP

DOI: 10.7176/PPAR/9-3-06

Publication date:March $31^{\text {st }} 2019$

\section{I: Background and Introduction}

Since 1950s, Pakistan has been relying heavily on foreign aid and external debt to meet its macroeconomic targets, including financing of current account deficit and developmental projects (Arshad, Aslam, Fatima, \& Muzaffar, 2015). Consequently, a heavy burden is imposed on each year's budget to account for debt servicing, including interest payments and rescheduling of loans. Through 1960s and 1970s, Pakistan was both encouraged and forced to take foreign grants, aids and loans to trigger sluggish economic performance and maintain economic stability within the country (Alin \& Bedir, 2015). More loans and infrequent repayments implied that the credit rating of the country went down, with future loans coming in at higher rates and stricter conditions by World Bank, International Monetary Fund and direct donors. While increasing foreign debt meant kickstarting many development projects, including infrastructural programs, it also implied increasing budgetary allocation for repayments, a general decline in national savings and foreign direct investment (Emori, 2015). A high external debt is thus, both a blessing and a boon in that it may bring opportunities to sustain and even expand the economic horizon, but at the same time may unfavorably tax future generations. As per (Easterly, 2002) and (Chenery, 1966) the main premise behind provision of external debt in developing countries is filling up the investment gap. The debt pours in investment projects and helps economic growth at one hand, while restrictions by the donor agencies and policy dictation by the lenders hinders the economy on the other.

This paper attempts to assess the impact of external (or foreign) debt on the economy of Pakistan for the democratic period between 2006-2017. Macroeconomic data for 12 years has been obtained from credible publications of State Bank of Pakistan and statistics reported in World Bank database.

1. Section I of this paper gives background, introduction and significance of the research

2. Section II presents an extensive analytical review and commentary on the trends of GDP and external debt between 1950-2017, with data elaborately explained in tables and figures along with descriptive statistics.

3. Section III presents review of the existing literature on the research topic.

4. Section IV deals with methodology for the current paper, including descriptive statistics and model summary.

5. Section $\mathrm{V}$ presents discussion on the results.

6. The last section i.e. section VI presents conclusion and recommends areas for further research.

\section{An Overview of External Debt and Economic Growth in Pakistan}

Soon after its independence in 1947, Pakistan had to face several challenges to sustain its economic standing. In order to take the first steps towards transforming the predominant agricultural country into a somewhat industry economy, Pakistan had to really heavily on international funding (Zaidi, 2015) . Gross Domestic Product was 
considerably low during the first two decades while external debt kept increasing. Political instability rampant during 1970s and 1980s because of wars, military coups and growing militancy in wake of Afghan war also took its toll on the economy with average GDP falling even less than during the 1960s (Husain, 1999). During the 1960 s, average GDP touched 6.8 percent while in 1970s and 1980s average GDP was 4.8 percent and 6.5 percent respectively (Zaidi, 2015). GDP further fell under 4.6 percent during the heavily instable period of the 1990 s. Four democratic setups were thrown out until a military regime led by General Pervez Musharraf returned in 1999. Inconsistent economic policies and political instability are cited to be the main reasons behind sluggish economic performing during the 1990s (Husain, 1999). After 2000, a slow upward movement returned to Pakistan, with 2005 bringing the highest GDP rate for the country's history.

Pakistan's external debt has been gradually increasing over the years. During 1972-1973, external debt was $\$ 4.38$ billion dollars, while the same increased to $\$ 10.9$ billion during 1986-87. The rapid increase of foreign debt during this phase is primarily attributed to the downward economic impact of the Afghan war.

For most part, Pakistan has been borrowing from the international community to finance the deficit arising out of balance of payments. In 2001, Pakistan's external debt crossed 50 percent of its GDP, with the country being classified into the list of heavily indebted countries by World Bank. Between 1998 and 2001, Pakistan rescheduled its external debt to meet the requirements of debt servicing.

In 2005-2006, Pakistan's GDP was recorded at \$137 billion, while foreign debt had risen to \$37.2 billion (Arshad, Aslam, Fatima, \& Muzaffar, 2015). It is pertinent to mention here that the period was characterized by a vicious circle of terrorism, internal displacement and sluggish investment by the private sector, but high inflows of remittances and FDI, which helped maintain economic stability for th country. In fact, GDP growth rate was highest in 2004-2005. In 2007, peace started to return with democratic setup in place, but the external debt kept shooting up and reached the magnitude of $\$ 65.1$ billion in 2015 and an alarming $\$ 91.7$ billion by end of fiscal year 2017, i.e. June 302018 (World Bank, 2018). Figure 1 shows movements in GDP and External debt for the period 2006-2017, while Figures 1 and 2 show the graphical presentation of the same. Figure 1: Gross Domestic Product for 2006-2017

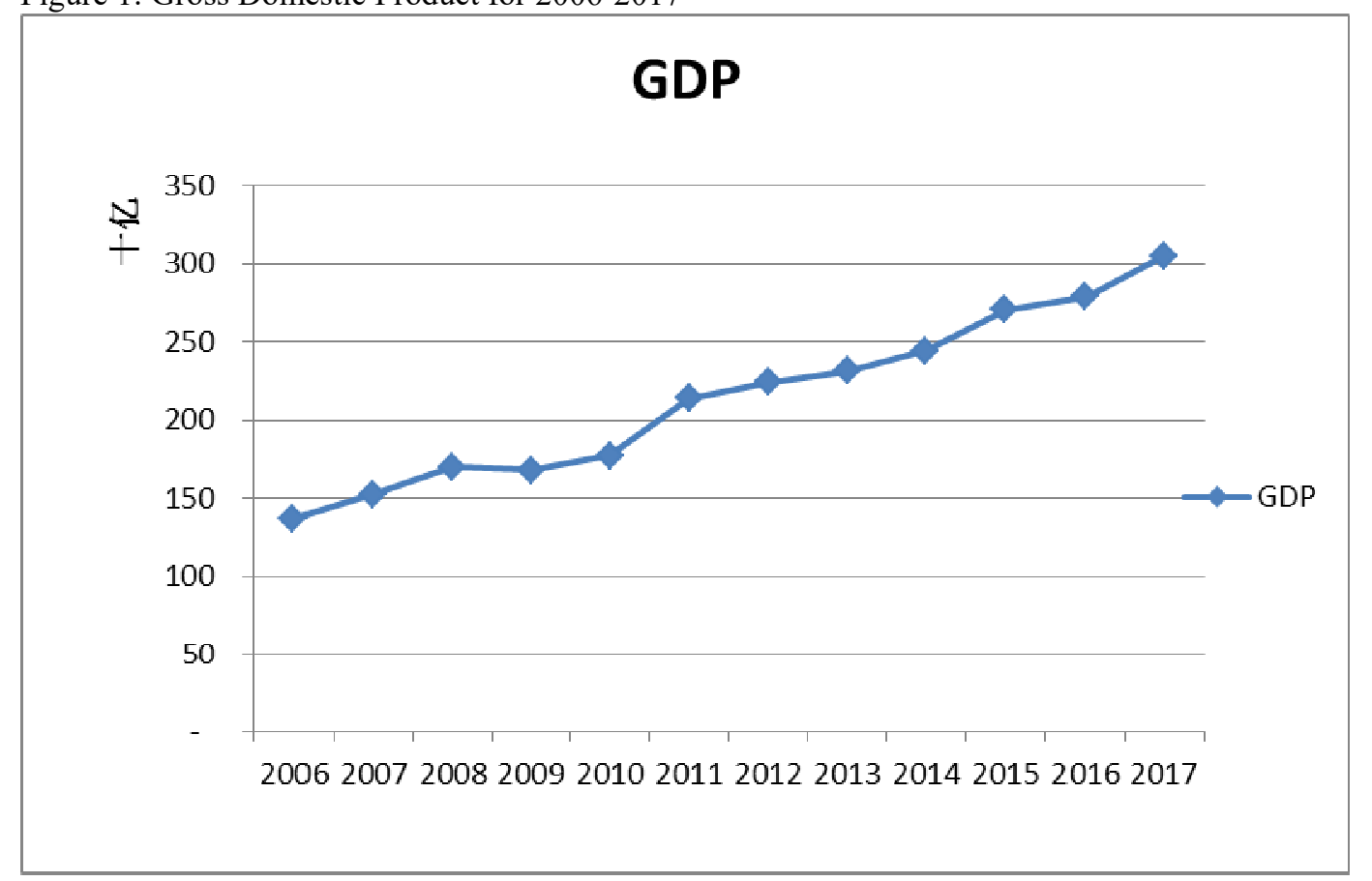


Figure 2: External Debt for 2006-2017

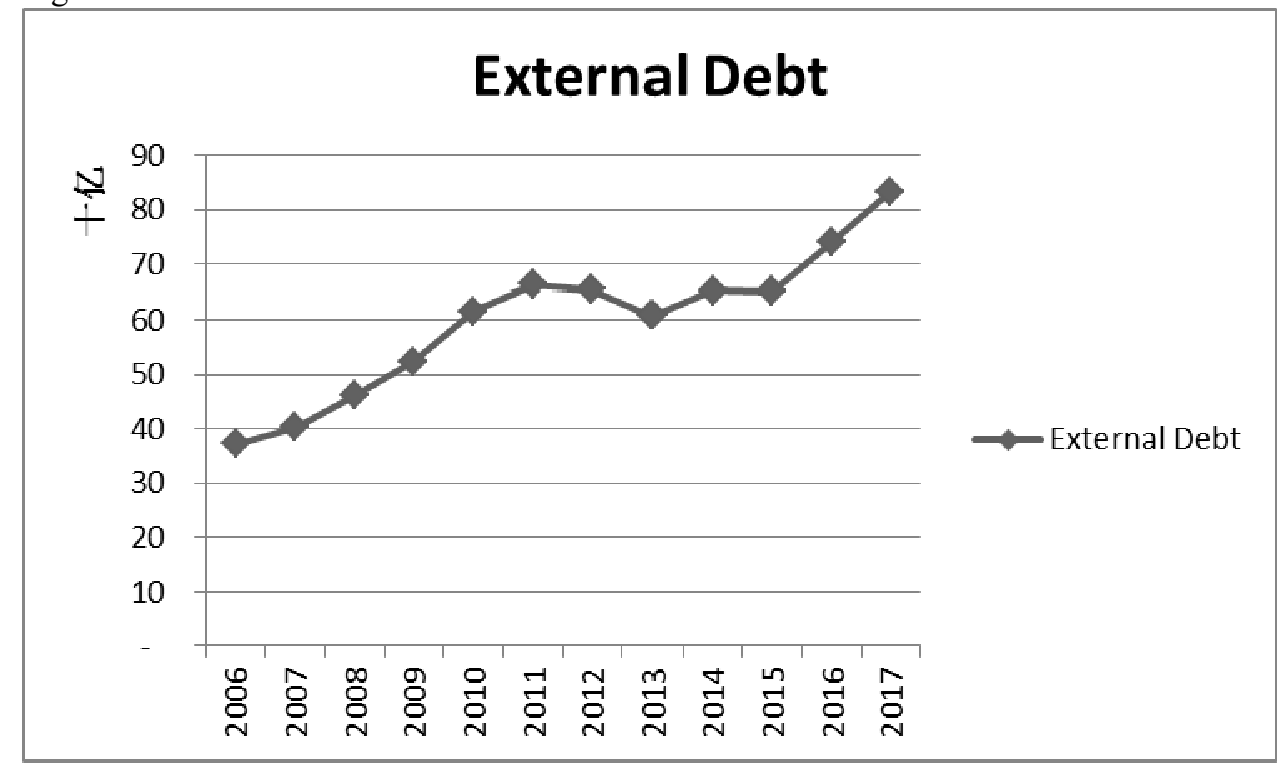

\section{SOURCE: World Bank; State Bank of Pakistan}

Serious debt problems started to hit the country in late 1990s, and during 2000s. Foreign liabilities of the country started shooting manifold in a matter of years, putting a great toll on Pakistan's yearly budget. Debt servicing alone took the biggest chunk from the annual budget, leaving little for developmental projects. Other macroeconomic indicators, such as gross savings and incidence of poverty also registered upward trends. However, during 2000s and 2010s, gross capital formation considerably improved, indicating long-term private investments within the country. Figure 2 and 3 show movements in gross savings and gross capital formation while figures 3 and 4 are graphical representation of the same for the period 2006-2017.

Figure 3: Gross Savings for 2006-2017

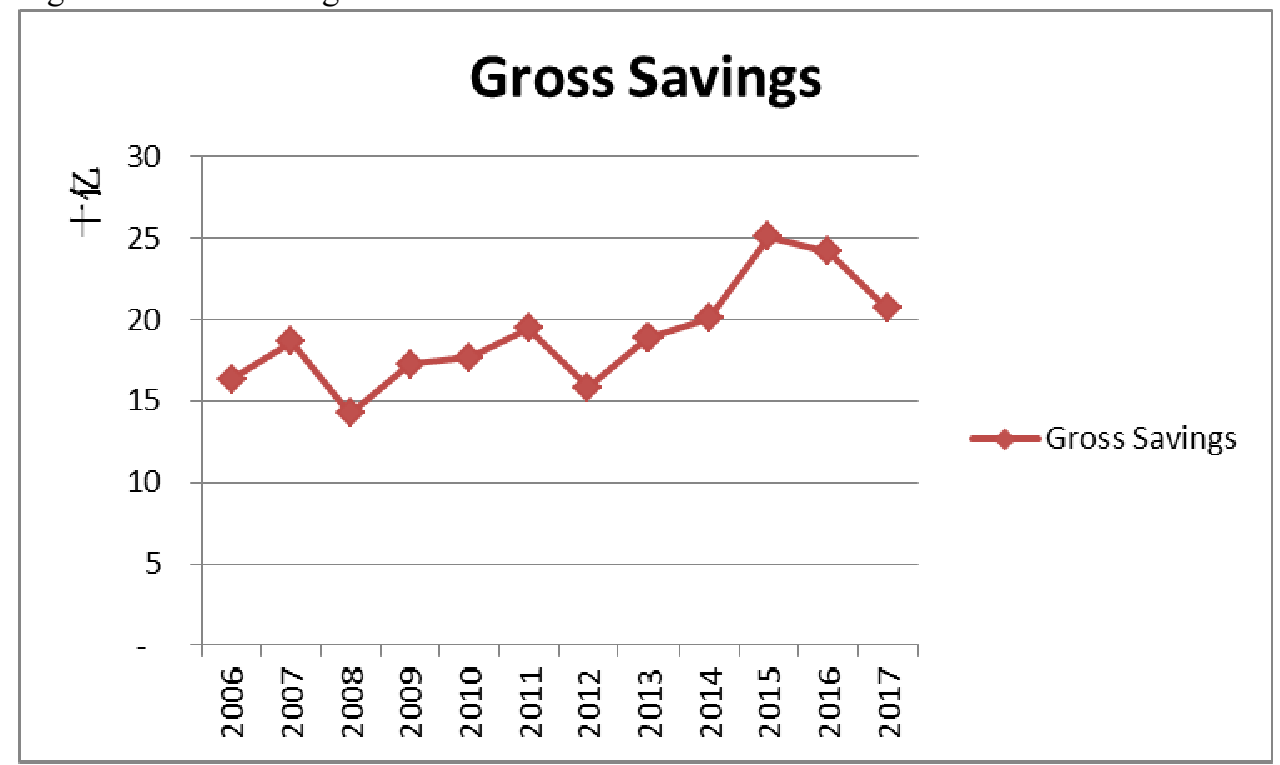


Figure 4: Gross Fixed Capital Formation for 2006-2017

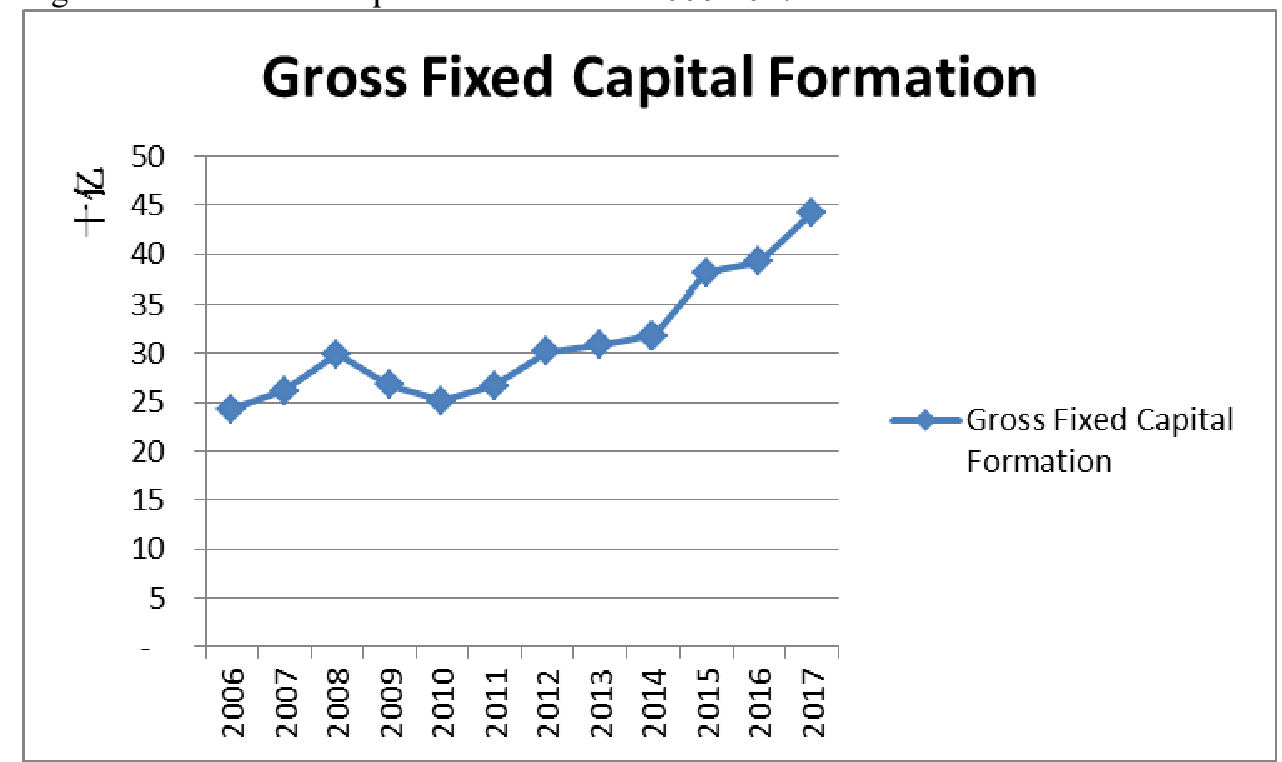

SOURCE: World Bank; State Bank of Pakistan

Figure 5: GDP Movement Along Other Macroeconomic Indicators between 2006-2017

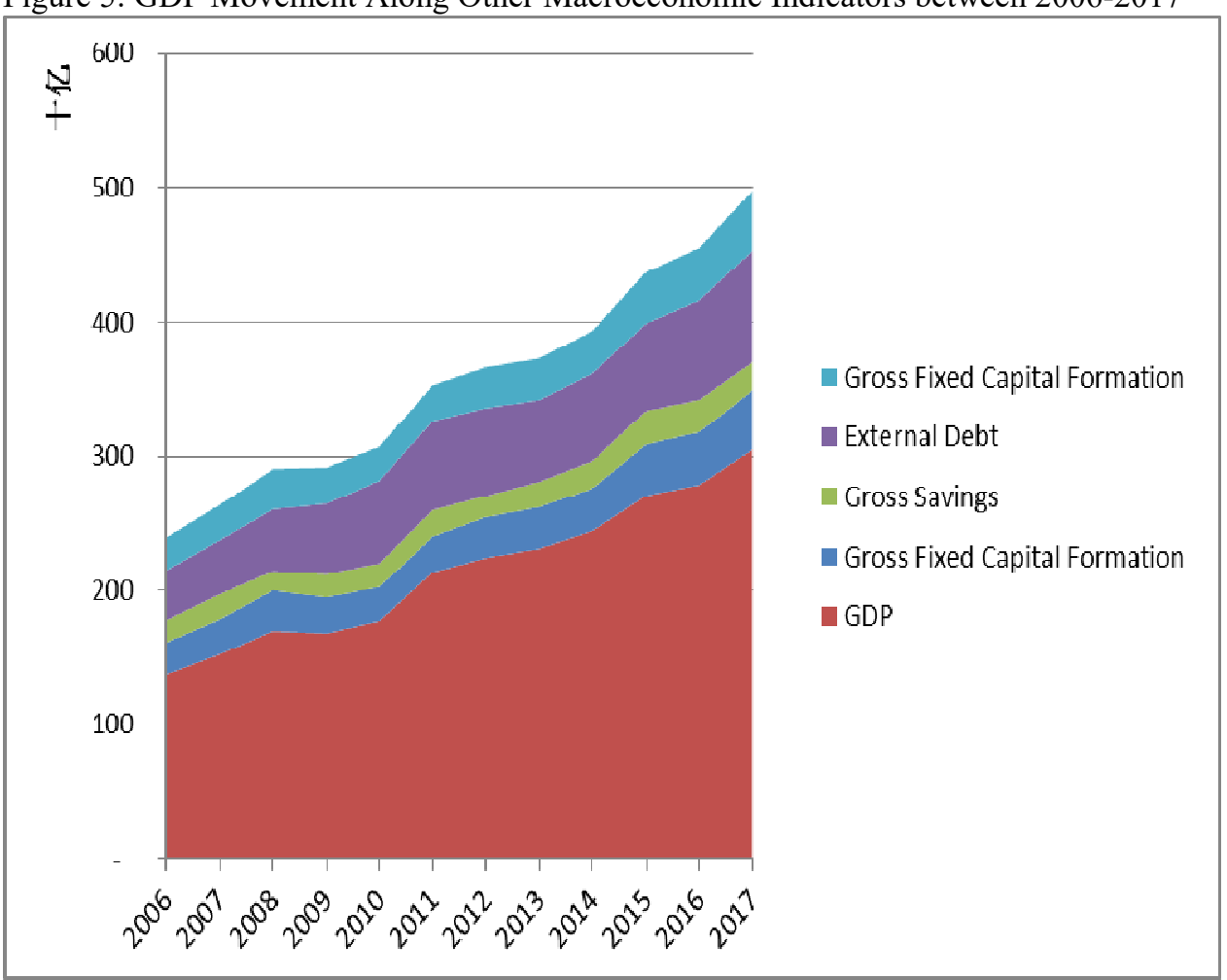

\section{Review of the existing literature}

Perasso (1992) using data from twenty middle-income severely indebted countries for the 1982-1989 period investigated the relationship between economic growth and external debt. The study shows that appropriate domestic policies have stronger impact on increasing investment and growth in highly indebted countries than decreasing debt-servicing obligation. Cohen's (1993) investigated the relationship between external debt and investment of developing countries for 1980's. The study shows that there is a little effect of level of stock of debt on investment. The author argued that an actual flow of net transfers affects investment. The study further reveals that actual service of debt "crowded out" investment. Cunningham (1993) investigated the relationship between debt burden and economic growth for sixteen countries for the period of 1971-2007. The study shows that growth of a country's debt burden has a negative effect on the economic growth. He also argued that when a 
country is significantly to foreigners, this adversely affects both labor and capital productivity. Chowdhury (1994) investigated the relationship between indebtedness and economic growth for Bangladesh, Indonesia, Malaysia, Philippines, South Korea, Sri Lanka and Thailand for the period of 1970-1988. They explored that external debt leads to mismanagement in exchange rate. The study further states that External debt does not affect the GNP growth rate. Metwally and Tamaschke (1994) employed Two Stage Least Square (2SLS) and Ordinary Least Square (OLS) method to investigate the relationship between debt servicing, capital inflows and economic growth for Algeria, Morocco and Egypt during 1972-2002. The results of the study show that capital inflows have a significant impact on the growth debt relationship. Sawada (1994) used annual time series data for sample period from 1955-1990 has shown that heavily indebted countries have debt overhang problems. Since their current external debts are above the expected present value of the future gains. Elbadawi et al. (1996) used cross-section data for ninety-nine countries to investigate the relationship also investigated the same relationship i.e. external debt and economic growth. The authors are of the view that current debt inflows as a ratio of GDP, past debt accumulation and debt service ratio have affected economic growth adversely. Amoateng and Amoako-Adu (1996) using the data pooled into time series and cross sectional form examined the relationship between external debt servicing, economic growth and exports for thirty-five African countries during 1971-1990. The study shows that that there is a unidirectional and positive causal relationship between foreign debt service and GDP growth after excluding exports revenue. 94 International Research Journal of Finance and Economics - Issue 44 (2010) Fosu (1996) examine the relationship between economic growth and external debt for the sample of sub-Saharan African countries for the period 1970-1986. The study reveals that on average a high debt country faces about one percentage reduction in the GDP annually. Deshpande (1997) investigated the relationship between external debt and investment 13 severely indebted countries for the period of 1971-1991 by using OLS method. The study shows that there exists negative relationship between external debt and investment. Olgun et al. (1998) employed 2SLS and 3SLS methods to investigate the relationship between capital inflows, foreign debt stock, investment and economic growth during the 1965-1997 period for Turkey. The study shows that there exists a two-way relationship between debt stock and debt service. The authors also pointed out that debt service does not affect economic growth. Iyoha and Milton (1999) investigated the relationship between external debt and economic growth for Sub-Saharan countries during the period 19701994. The study shows that external debt has adversely effect investment. The study also pointed out that reduction in debt stock would lead to improvement in investment and economic growth. The authors stressed that debt of these countries should be forgiven to stimulate economic growth. Fosu (1999) has employed an augmented production function to investigate the impact of external debt on economic growth in sub-Saharan Africa for the 1980 -1990 period. The study reveals that there is a negative relationship between debt and economic growth. The study also shows that a rather weak negative impact of debt on investment levels. Karagöl (2002) examined relationship between economic growth and external debt service for turkey during 1956-1996. The author used multivariate co-integration techniques. The study shows that there exists a negative relationship between external and economic growth in the long run. Granger causality test results showed a uni-direction causality running from debt service to economic growth. Abdelmawla and Mohamed (2005) investigated the impact of external debt on economic growth during 1978-2001 of Sudan. The study reveals that external debt and inflation adversely affected the country's economic performance. The study also shows that export earnings have significantly positive impact on economic growth. Chaudhary (1998) investigated that whether Pakistan will accumulate a heavy burden of foreign debt if the present tendency of borrowing is to continue. The author has evaluated the impact of trade and saving on the external debt. The study reveals that if Pakistan has to reduce its debt burden than trade policy is more favorable than saving policy. Ahmed (1997) used three-gap model to investigate the external debt problem of Pakistan. The author suggested that if Pakistan has to reduce its debt burden that it has to focus on fiscal policy measures. These fiscal policy measures can be changes in tax rate, government consumption and public expenditure expenditures Ahmed (2001) used three-gap dynamic model of macroeconomic model of macroeconomic equilibrium to analyze the external debt problem of Pakistan. The author is of the view that if the pattern of external debt continues than Pakistan's foreign debt position will further deteriorate in the future. Like the above-mentioned studies on the relationship between external debt and growth in Pakistan, several economists have tried to find out the role of foreign aid in economic development of Pakistan. As, Shabbir \& Mahmood (1992) and Khan \& Rahim (1993) concluded that the aid has accelerated the rate of growth of GDP. Aslam (1987) examined that the public FCI did not affect the domestic investment significantly, while the private FCI covered the domestic saving-investment gap. Some other studies were carried out to analyze the impact of aid on savings in Pakistan. Khan, Hasan and Malik (1992) estimated that the FCI caused to decline national savings in Pakistan during the period of 1959-60 to 1987-88. Shabbir and Mahmood (1992) also found the negative impact of foreign capital on the national savings in Pakistan for the same period. Mahmood (1997) found that country may caught in a sever debt problems due to macroeconomic mismanagement, misutilization of aid and inappropriate policies.

There are a large number of studies which have been conducted by the different economists and the 
researchers having a goal to check that either the external debt effects the growth of the country or not. The economists and researchers apply different techniques and methods to find the relationship. They have found mixed relationship and conclude different results; the studies of the researchers show that external debt affects the growth of the country significantly while on the other hand some researchers are failed to draw the same result. Researchers used different type of variables to conclude the effect of external debt to the growth of the country. Some of the conclusions made by the researchers are given below: (Arshad, Aslam, Fatima, \& Muzaffar, 2015) has conducted a research to investigate whether the foreign debt lead the economic growth of the country in the longer run or not. In regard to this a time series data from 1970-2014 are taken and ordinary least square method is used in this regard. (Lee $\& \mathrm{Ng}, 2015$ ) Has conducted o study to check whether the variables such as external debt and budget expenditure having an impact on economic development. A data from 1971-2003 is taken and the results shows that there is a negative of public debt on Gdp. (Zafar, Sabri, ilyas, \& kousar, 2015) has conducted a study to investigate whether the external debt is having a positive impact on economic growth or not. Unit root test has been applied and the results show that there is negative impact of external debt in economic development of a country. (Emori, 2015) Has conducted a study to examine the impact of the external debt on the economic growth of Nigeria. The co integration method is used and the results show that impact of external debt having a positive impact on economic growth of Nigeria. (alin \& bedir, 2015) Has conducted a study and the study aims to check the role of external debt on the economic growth and date from 1985-2013 has been taken and the results shows that there is negative impact of external debt in the economic growth of a country. (hussain, haque, \& IGWIKE, 2015) Has conducted a research to find that is debt is a burden for economic growth and the data from 1995-2012 has been taken and garner causality test is applied and the results shows that there negative correlation between the gdp and debt. (Mencinger, Aristovnik, \& Verbic, 2015) Has conducted a study to find out the role of external debt in growing economies and a data from 1980-2010 is taken and the results shows that there Is a positive negative correlation between debt to gdp ratio. (Lahiani \& d'Orléans, 2015) Has conducted a study to find out is external debt effected the economic growth of South Africa? The results from 1980-2014 has been taken and the results show that there is a positive relation of external debt in the economic growth of South Africa. (cuestas \& regis, 2015) Has conducted a study to check the level of sustainability of external debt . the results from 1984-2013 has been taken and the results has shown that there is a positive relation of external debt in economic growth.

\section{Methodology and Discussion}

The study limits the data for the research for the period between 2006-2017. The reason for this data is to statistically analyses and test the macroeconomic indicators for GDP and external debt for the longest democratic period in Pakistan's history. Data was primarily sourced from statistics published by State Bank of Pakistan, Economic Survey and World Bank.

For the purpose of this research, GDP is used as an dependent variable while External Debt is used as the primary independent variable. Secondary independent variables include gross savings (GS) and Gross Fixed Capital Formation. The explanation of these variables are given as under:

\section{Explanation of Variables}

1. GDP, the independent variable in this research, represents the total value of all goods and services produced by resources of Pakistan. The GDP used in the research is at constant, or purchaser prices in local currencies before being converted into dollar values for the given period.

2. External Debt, or foreign debt of Pakistan, represents total loans from IMF (federal government and central bank), foreign exchange liabilities (including central bank deposits and FDR), PSE gurantted and nonguaranteed debt and government debt comprising of long-term loans through multilateral/bilateral arrangements, Euro/Sukuk bonds, Paris Club, SAFE China deposits, military debt, Saudi Fund for Development, and short-term loans such as those from IDB and T-bills.

3. Gross Fixed Capital formation (GCF) Gross Fixed Capital Formation refers to the net increase in physical assets such as infrastructure within the measurement period. It does not account for the consumption (depreciation) of fixed capital, and also does not include land purchases.

4. Gross Savings (GSD) In order to arrive at gross savings, we take the sum of savings reported by private corporate sector, household sector and the public sector.

The governing equation for the above variables uses the general form for the model GDP $=\alpha 0+\alpha 1($ eds $)+$ $\alpha 2$ (gcf) $+\alpha 3(\mathrm{gds})+\varepsilon i(1)$, where GDP is the gross domestic product at constant price, ed is external debt, gcf is gorss capital formation and gds is savings. Descriptive statistics for the given data is first presented, followed by application of Ordinary Least Square (OLS) regression. The OLS method takes in logarithm zed data and determines the relationship between the dependent and the independent variable(s). The method corresponds to minimizing the sum of square differences between the observed and predicted values. In implementing the model, each variable is regressed on a constant, a linear deterministic trend, a lagged dependent variable and $\mathrm{q}$ 
lags of its first difference. The null hypothesis Ho: $\rho=0$ was tested against the one-sided alternative H1: $\rho<0$ in equation above.

Descriptive statistics

\begin{tabular}{|c|c|c|c|c|}
\hline Statistical Measures & External & GDP & Gross_Fixed_Capital & Gross_Saving \\
\hline Mean & $5.98 \mathrm{E}+10$ & $2.14 \mathrm{E}+11$ & $3.12 \mathrm{E}+10$ & $1.90 \mathrm{E}+10$ \\
\hline Median & $6.34 \mathrm{E}+10$ & $2.19 \mathrm{E}+11$ & $3.01 \mathrm{E}+10$ & $1.88 \mathrm{E}+10$ \\
\hline Maximum & $8.34 \mathrm{E}+10$ & $3.05 \mathrm{E}+11$ & $4.42 \mathrm{E}+10$ & $2.51 \mathrm{E}+10$ \\
\hline Minimum & $3.72 \mathrm{E}+10$ & $1.37 \mathrm{E}+11$ & $2.43 \mathrm{E}+10$ & $1.42 \mathrm{E}+10$ \\
\hline Std. Dev. & $1.36 \mathrm{E}+10$ & $5.40 \mathrm{E}+10$ & $6.27 \mathrm{E}+09$ & $3.19 \mathrm{E}+09$ \\
\hline Skewness & -0.202 & 0.170 & 0.877 & 0.558 \\
\hline Kurtosis & 2.331 & 1.820 & 2.594 & 2.599 \\
\hline Jarque-Bera & 0.305 & 0.754 & 1.622 & 0.702 \\
\hline Probability & 0.859 & 0.686 & 0.444 & 0.704 \\
\hline Sum & $7.810 \mathrm{E}+11$ & $2.570 \mathrm{E}+12$ & $3.740 \mathrm{E}+11$ & $2.280 \mathrm{E}+11$ \\
\hline Sum Sq. Dev. & $2.030 \mathrm{E}+21$ & $3.200 \mathrm{E}+22$ & $4.330 \mathrm{E}+20$ & $1.120 \mathrm{E}+20$ \\
\hline Observations & 12 & 12 & 12 & 12 \\
\hline
\end{tabular}

Source: Authors calculations using statistical software E-views 3.1

Model Summary

Dependent Variable: GDP

Method: Least Squares

Date:07/02/18

Sample: 20062017

\begin{tabular}{|c|r|r|r|r|}
\hline Variable & \multicolumn{1}{|l|}{ Coefficient } & Std. Error & \multicolumn{1}{l|}{ t-Statistic } & Prob. \\
\hline C & $-6.85 \mathrm{E}+10$ & $2.14 \mathrm{E}+10$ & -3.19837 & 0.0126 \\
\hline External_Debt_EDS_ & 1.99945 & 0.401551 & 4.979319 & 0.0011 \\
\hline Gross_Fixed_Capital_Formation & 3.707978 & 0.95671 & 3.875757 & 0.0047 \\
\hline Gross_Savings_GDS_ & 2.51106 & 1.486141 & 1.689565 & 0.1296 \\
\hline R-Squared & 0.967084 & Mean dependent var & $2.14 \mathrm{E}+11$ \\
\hline Adjusted R-Squared & 0.954741 & S.D. dependent var & $5.40 \mathrm{E}+10$ \\
\hline S.E. of regression & $1.15 \mathrm{E}+10$ & Akaike info criterion & 49.42679 \\
\hline Sum squared resid & $1.05 \mathrm{E}+21$ & Schwarz criterion & 49.58843 \\
\hline Log likelihood & -292.5607 & Hannan-Quinn criter. & 49.36695 \\
\hline F-statistic & 78.34878 & Durbin-Watson stat & 0.712718 \\
\hline Prob (F-statistic & 0.000003 & \multicolumn{3}{l}{} \\
\hline
\end{tabular}

Source: Authors calculations using statistical software E-views 3.1

Equation

Based on the general form for the model equation above, the tests get the following deterministic regression line. $\mathrm{GDP}=-68549038542+2(\mathrm{EDS})+3.7(\mathrm{GCF})+2.5(\mathrm{GDS})$

After application of the OLS regression for the above equation, EDS or External Debt was found to be statistically significant while GDS or Gross Savings was found to be statistically insignificant.

\section{V: Conclusions and Recommendations}

The study was undertaken to thoroughly analyze the extent and impact of external debt over the years and its relationship with the economic as indicated by gross domestic product or GDP. Until 2006, the country has borrowed extensively to finance its investments gap and account for deficits in balance of payments. Decades of external financing and rescheduling of loans have led to a vicious circle of debt for Pakistan, which stood over $\$ 83$ billion in 2017 and jumped to an alarming $\$ 91$ billion in 2018. Pakistan agreed upon strict and often unfavorable terms imposed upon by IMF and World Bank, the primary lenders of debt for the country.

The results of the research are consistent with results of the previous studies, except in that the relationship between GDP and savings has been found to be statistically insignificant. Based on the findings, it is suggested that the policy makers emphasize on developmental activities while considering external debt. The results also imply that the external debt as a vehicle for budget and BoP financing would adversely affect the economic growth. Policymakers are advised to consider the plans for exchange rate, fiscal stance, interest rate and pricing before procuring external debt. Avenues other than external debt include, but are not limited to, domestic and foreign investment, export-led growth, domestic savings and investments in human capital. 


\section{References}

Alin, S., \& Bedir, S. (2015). EXTERNAL DEBT AND ECONOMIC GROWTH: NEW EVIDENCE FOR AN OLD DEBATE. Journal of Business, Economics \& Finance, 500-522.

Arshad, Z., Aslam, S., Fatima, M., \& Muzaffar, A. (2015). Debt Accumulation and Economic Growth: Empirical Evidence from Pakistan Economy. International Journal of Economics and Empirical Research, 405-410.

Bank, W. (2018). The World Bank In Pakistan: Country Overview. Retrieved from http://www.worldbank.org/en/country/pakistan/overview

Chenery, H. a. (1966). Foreign Assistance and Economic Development. American Economic Review 56(4), 679-733.

Cuestas, J. C., \& Regis, P. J. (2015). The Sustainability of European External Debt: What have We Learned? Review of International Economics, 445-468.

Easterly, W. (2002). How Did Heavily Indebted Poor Countries Become Heavily Indebted? Reviewing Two Decades of Debt Relief. World Development, 30(10), 1677-1696.

Emori, E. G. (2015). The Impact of external Debt on Nigerian Economic Growth. Archives of Business Research, 69-80.

Husain, I. (1999). Pakistan: the economy of an elitist state. Karachi: Oxford University Press.

Zaidi, S. A. (2015). Issues in Pakistan's economy: a political economy perspective. Oxford: Oxford Univ. Press. 